\title{
The Effects Of Grammar Mastery And Vocabulary Mastery Towards Student's Reading Comprehension In Expository Text
}

\author{
Etik Dwi Styaningrum
}

\author{
Universitas Bina Sarana Informatika Jakarta \\ etik.eds@bsi.ac.id
}

\author{
Cara Sitasi: \\ Styaningrum, E. D. (2019). The Effects Of Grammar Mastery And Vocabulary Mastery Towards Student's \\ Reading Comprehension In Expository Text. Wanastra, 11(1), 89-100.
}

\begin{abstract}
The main aim of the research is to find out whether there is significant effects of Grammar Mastery and Vocabulary Mastery towards Students' Reading Comprehension in Expository Text.The research was conducted at SMKN 1 Cikarang of tenth grade students with the total sample 40 students that randomly taken and at SMKN 2 Cikarang of tenth grade students with the total samples 40 students that randomly taken. The method used in the research was a survey. Data of grammar mastery, vocabulary mastery and reading comprehension were acquired from the tests. The data was analysed using descriptive statistical method, multiple correlation coefficient, determination coefficient and regression analysis. To test the statistics is used $T$ test and $F$ test. The result of the research concluded that there are significant effect of Grammar mastery and vocabulary mastery towards student's reading comprehension in expository text.
\end{abstract}

Keyword : Grammar Mastery, Vocabulary Mastery, ,Reading Comprehension, Expository Text

\section{INTRODUCTION}

Reading competence is the important factor in modern society that each individual has to search for information through the medium of reading because information, knowledge and technology are mostly found in written or printed material. The ability will enables students to gain information and to improve their knowledge.. Thus, one of the language skills that the students can rely on is reading. Reading is an appropriate medium to promote life long learning.In study of English, there are many types of written text are available. One type of written text is expository text. The author uses expository writing to inform the reader about the topic. At school, students are required to submit school exams and research papers as a means for the teachers to grade the progress. At work, people are required to produce business report and memorandums to inform the superiors and co workers about the occurrences that take place at other levels of the company.

In addition, oral exposition is primarily observed in oral academic presentation, business talks, and speeches that are delivered to a group of people. As each of these different cases illustrate, expository writing and speech surround the readers in every day life. It means that by understanding expository texts, the students that are obliged to do their academic tasks such as writing research papers, speeches and other academic presentation will be helped.

For students, reading expository texts is absolutely important. Success in school work and society depends on largely upon the ability to comprehend this type of text. Based on observations, most of students in SMKN 1 Cikarang Selatan and students of SMKN 2 Cikarang Barat experienced difficulties in reading comprehension. Newman ( 2007) explains that an important goal of education is to assist students to read and write expository texts. Researchers noted establishing effective instructional frameworks for teaching students how to read and write this material remain elusive, therefore, developing effective expository reading comprehension instruction should be a research priority. As defined by Partnership for Reading ( 2005 ) Reading comprehension is understanding a text that is read, or the process of " constructing meaning " from a text. Comprehension is a "construction process" because it involves all of the elements of the reading process working together as a text is read to create a representation of the text in the reader's mind.

The ultimate goal in reading is to make meaning from text that is to comprehend the information conveyed by in the text. It means that the reader should gain some understanding of the message conveyed by the author. Not only that, 
comprehension should go beyond simply understanding the explicit message that is being conveyed by the author. To truly comprehend texts is to make connection between the information in the text and the information in the reader's head to draw interferences about the author's meaning to evaluate the quality of the message and possibly even to connect aspects of the text with other works of literature.

The prior of background knowledge is the knowledge achieved in previous readings or learning. One of the most important prior knowledge is the knowledge of vocabulary. It is undeniable that to be skillful in reading, one needs sufficient vocabulary. Vocabulary is one of the important elements needed in reading because it is the stocks of words. Developing superior vocabulary knowledge is extremely required to understand the whole text easily. Freebody ( 1979) stated that the number of the words as reader knows is a predictive of his ability to comprehend the text. That is to say that vocabulary gives high contribution to students' reading comprehension and it is important to prove the contribution by conducting a research i.e. investigating the correlation between vocabulary mastery and comprehension of expository text.

Another prior knowledge is the knowledge of grammar. Grammar in Indonesia schools is sometimes replaced by the term structure. The knowledge of grammar is important in mastering a language because grammar intersects and overlaps with the four language skills.

Grammar is the science of language. As every field of study depends on its own rules to evolve, language has its own rules defined under the cute name of 'Grammar.' 'Grammar' hails from grammaire (French), grammatikos (Greek), or grammatica (Latin), all meaning "relating to letters," according to the Oxford Concise Dictionary.

Why we require grammar to our writing is often disputed. Spoken communication usually expands outside the boundaries of grammar and draws its own territories, usage rules of speech. Written language, however, retains the same old forte of usage rules, and ever since showed inhibition to come out.

Spoken language is used by the speaking lot in millions, while written language is the realm of writing lot, in thousands. In a world of entropy (disorder), it is easier to assume that there are more disorganized people in a million than in a thousand; moreover, the recognized writers are authorities of language, who get published and become famous for the sheer excellence of their language. A language is more elegant, beautiful, and legible when it goes by the rules of grammar, usage, and style. While everyone of these is equally important, slips in grammar makes it all worthless. Proper grammar enables you to publish content online or offline with reputed publishers. That itself is a reward, even if you don't earn much by publications.

The lack of knowledge of grammar will result in the grammatically incorrect sentences which can lead to misunderstanding of what one is saying or writing. Further, knowledge of grammar is important in comprehension because complexity of grammar can cause difficulty. A simple clause is easier to understand than a complex cause. If there are more complex clause that simple clauses, the complexity of the text in the term of grammar is high. Readence, Bean and Baldwin ( 1985) stated that reading a text is an interactive process of the grammar competence owned by the reader.

\section{THEORETICAL REVIEW}

\section{Grammar Mastery.}

Grammar mastery is the mastery of formal rules concerning word forms and application of words in a sentence to create correct and meaningful sentences. Grammar mastery is the understanding of sentence structure, sentence element, and also includes the understanding of simple clause and complex clause. In this research, the researcher discusses grammar as the system of rules of forming words and combining them into sentences.

Riemsdijk and William ( $1986: 4$ ) says that the system or set of principles from putting words together into sentences is called grammatical rules. A sentence consists of three things ; sound meaning, and syntactic structures. In other words, grammar in the rule for putting sounds, meaning and syntactic structures together to make meaningful sentences.

Richards ( 1985) argues that the factors involved in knowing a language are grammatical competence, communicative competence, and language proficiency. Gerot and Wignell ( 1994:2) explains that grammar is a theory of language, of how language is put together and how it works. More particularly, it is the study of wordings. In a sentence such as Time flies an arrow, this string of language means something; the meaning is accessible through the wording; that is the words and their order and the wording in turn, is realized or expressed through sounds or letters. 
All languages in use can be analyzed at four levels ; text, sentence, word and sound. These are the forms that language takes. The study of grammar consists, in part, of looking at the way these forms are arranged and patterned. It is partly the study of what forms ( structures ) that are possible in language. It concerns almost exclusively with the analysis at the level of sentences. Thus, it is a description of the rules that govern how language's sentences are formed.

Brown ( 2001:362) ascertains that grammar is the system of rules governing the conventional arrangement and relationship of words in a sentence. The components of the words ( prefixes, suffixes, roots, verb and noun endings, etc ) are parts of grammar. Technically, grammar refers to sentence level rules only, and not the rules governing the relationship among sentences which refer to discourse rules.

From a foreign learner's point of view, the major difficulty in English grammar is the difference between pronunciation and written forms. Otherwise, English is a language that can be acquired more rapidly in the early stages than many others. In intermediate and advanced stages, however, everything becomes more confusing because rules are complicated by idiomatic expression.

Most people judge one's English from the way one speaks or writes whether one has good grammar or not. Brown ( 1991) argues that grammar is one of the aspects that operate language. The study of grammar includes both syntac and the inflection of morphemes. Thornbury ( 2002:2) asserts that the system of rules that covers the order of words in a sentence is called syntax. Syntax rules disallow; Not we at right home now are. The systems of rules that cover the formation of words is called morphology. Morphology rules disallow. We is not at home right now. Therefore, grammar is seen as the study of the syntax and morphology of sentences.

In speaking, one with little knowledge of grammar can still make himself understood with the help of signs, gestures or symbols. Expressions like "long time no see" or "no can do" are sometimes used in spoken English. On the other hand, in writing, in order to convey intelligible messages, it is absolutely imperative that one employs good grammar. In the following pair of sentences, it can be noticed how pronouns "me" and "mine" change the meaning of the sentences in English but both sentences can be read the same in Indonesia.
Language skills cover the four main aspects of language, namely: listening, speaking, reading, and writing. Grammar has always been a central aspects of language. It is undeniable that grammar covers the four aspects of language skills. Oxford ( 1989) states that grammar intersects and overlaps with the four language skills. Du Toit and Orr ( 1987) argues that grammar is important because grammatical mistakes can be lead to misunderstanding what one is saying or writing and because grammatical mistakes can give people a very bad impression of the speaker. For example, If one says My mother punished me for coming late and the listener will know that his mother does the punishment in the past time, as grammar can

be used to denote time sequence. In addition, Jeffery ( $1990: 120$ ) states that grammar is needed in order to gain control of written language for thought has to be organized in order to make meaning clearer to readers.

Clearly, grammar is an important element and occurs in the four language skills. Grammar is prominent as a organizational framework within which language operates. Grammar is used in speaking and writing, When one listens to speech, grammar is there and in reading pieces, the use of grammar ( tenses is varied which is often based on the intention of the writer. Thus, knowledge of grammar is important because grammar complexity may cause difficulty in understanding texts. Grammatical complexity refers to how a clause complex appears in a text in comparison with simple clauses, It is accepted that any text has a different level of complexity. This is all related to how much information is introduced in a clause complex which can be more than one simple cause. A clause ( dag hammarskjold left the Congo city by plane ) is less complex than the clause ( the situation is difficult for Dag hammarskjold, the secretary of General of the UN at the time to deal with because among the members of the organization were several groups of nations which strongly supported quite different views about the problem ) in the sense that the latter presents more information. This is due to the fact that English allows for the information of clause complex which is embedded in a sentence.

In this case, there are types of sentences ( clauses ) that are related to the grammatical complexity. The term complexity suggest that there is more information presented in a sentence by the application of a clause complex. Frank ( 1972:220) divides sentences ( clauses ) into 4 types based on the complexity, namely ( 1 ) Simple Sentence. It has only one subject and one predicate or it has only one finite verb : e.g. John bought bananas: 
(2) Compound Sentence. It is made up two or more principal or main Clause : e.g. John came in and Mary prepared tea (3) Complex sentence. It consists of one main Clause and one or more Subordinate Clauses : e.g. John came in when Mary was preparing tea. (4) Compound Complex Sentence. It contains two or more main or Independent Clause and one or more Subordinate or Dependent Clauses: e.g. John bought bananas and marry prepared tea so what that could enjoy the party.

\section{Vocabulary Mastery}

According to Hornby ( $1987: 523$ ) mastery is a complete of knowledge. Mastering vocabulary, thus it deals with the complete control or words knowledge or the ability to know the meanings of certain vocabulary items and their usage in certain context to express ideas, opinion and feelings in communication. Vocabulary mastery is people's ability to use or to understand words of language that they have learned in certain situations which they really have experienced in their lives.

Chapelle ( Read, 2000:28 ) stated that vocabulary is defined comprehensively as a general construct of language ability; it is includes knowledge of language and the ability to put language to use in context. The dimensions of this components according to Chapelle ( read, 2000:31) includes vocabulary size, knowledge of word characteristics. Brown ( 2001:337) asserts that vocabulary is basic building blocks of languages. Vocabulary is closely related to eight parts of speech namely; verb, noun, adjective, adverb, pronoun, preposition, conjunction, and interjection. Gleason and Ratner ( $1998: 422$ ) argues that development of vocabulary knowledge represents a continuum in which individual words move from unfamiliar to acquainted, and to established categories. This vocabulary development both pushes and is pushed forward by reading acquisition. The interconnectedness of reading and vocabulary development is shown by the influence of each to the other where advances on each influence the other. The reciprocal causation relationship exist in older impaired readers where these readers develop problems in vocabulary knowledge as the result of delays in reading, which then became further impeded because of increasing vocabulary deficits.

Vocabulary takes a very important role in learning a language including English. If one has a good deal of vocabulary, one can have some facilities in speaking and writing as long as one knows the meaning and the function of each of the vocabulary. As Nunan ( $1990: 101$ ) ascertains that vocabulary are more than lists of target language words. As a part of the language systems, vocabulary is intimately interrelated with grammar. In fact, it is possible to divide the lexical system of most languages into grammatical words such as preposition, articles, adverbs, content words and so on. The grammaticality of vocabulary also manifest itself in word morphology, that is, the grammatical particles that are attached to the beginning and ends of words in order to form new words.

Nunan ( 1999 ) explains that in recent years, the teaching of vocabulary has assumed its rightful place as a fundamental aspects of language development. This is partly due to the influence of comprehension - based approaches to language development, partly due to the research efforts to influential applied linguistics, and partly due to the exciting possibilities opened up by development of computer language corpora. Nunan ( 1999 ) says that proponents of comprehension-based approaches to language acquisition argue that the early development of an extensive vocabulary can enable learners to out perform their competence. In other words, if one has an extensive vocabulary it is possible to obtain meaning from spoken and written texts which are encoded. Norbert

( 1997 ) argues that knowledge is always a prerequisite to the performance of language skills. Vocabulary knowledge enables language use, language use enables the increase of vocabulary knowledge; knowledge of the world enables the increase of vocabulary knowledge; knowledge of the world enables the increase of vocabulary knowledge and language use and vise versa.

Nation ( $1990: 22$ ) contends that the main goal of vocabulary learning is to increase the students' vocabulary mastery in order to master the four language skills, listening, speaking, reading and writing vocabulary learning goals will be achieved by doing receptive and productive learning. Receptive learning involve being bale to recognize a word and recall its meaning when it is met. Productive learning involves what is needed for receptive learning plus the ability to speak or to write needed vocabulary at the appropriate time. If learners study English in order to be able to read and understand lectures, receptive knowledge of vocabulary is needed. If learners need to cover the whole range of language skills, the a productive knowledge of vocabulary and large receptive vocabulary is needed.

Wallace ( $1982: 9$ ) argues that there is a sense in which learning a foreign language is basically a matter of learning vocabulary in target language. Robert ( 1995 : 367 ) states that vocabulary is prerequisite for reading comprehension, in which people who do not know the meanings of words are most probably poor readers. Davis ( 1968 ) says 
that the factor that correlates most highly with comprehension, in which people who do not know the meanings of words are most probably poor readers. The number of words reader knows is predictive of his ability to comprehend the text. Ames ( 1964 ) also suggest that knowledge of word meanings is probably the best index for predicting achievement in reading.

The fact that written language is complex is recognizable; the complexity lies on the lexical density is how the information is put in a clause form . If there is a high proportion of vocabulary items used in every clause, the text are dense. In this case, the lexical density may cause difficulty in comprehension. Readers should have a large amount of vocabulary to understand texts. Thombury ( 2002 : 14 ) explains that vocabulary acquisition is the largest and most important task faced by the language learner, the most basic level of knowledge a word involves knowing its forms and its meaning. Knowing a word does not only know the words commonly associated with it (its collocations ) but also its connotations, including its register and cultural accretions.

Vocabulary mastery is the process to comprehend English vocabulary learned from the messages communicated. The mastery of vocabulary can be classified into

1. The vocabulary mastery as the result of learning and the vocabulary as the effect of environment;

2. Vocabulary mastery acquired through the environment including family, social interaction and so on. Development of vocabulary starts from childhood and continuous to long life.

Thus from the discussion above, it can be said that the quality and quantity of vocabulary mastery are the important either to comprehend or to produce ideas and thoughts. So, the vocabulary mastery is the ability to understand English vocabulary to comprehend and produce English.

Vocabulary mastery is not a spontaneous process, but a gradual process which aims to master Vocabulary solidly. According to Kerlinger ( 1970 ), someone's vocabulary goes through three stages, namely, childhood stage, adolescence stage and adulthood stage. The first stage is childhood stage; in this stage, the child wants to know words to express whatever he can identify by using his faculties, especially something which relates to his main needs. The second stage is adolescence; at this stage there is an additional processing which is called the language learning process. The child who has become a teenager begins to study to master his language and broaden his vocabulary still runs together with that of the childhood stage. The third stage is the adulthood stage. At this stage, the vocabulary mastery of the child is more stable because the child who has become an adult has many opportunities to be involved in communication broadly and freely. Basically, a student commonly interested in identifying and studying new words, if he hears and reads new words. He will always try to master it until he reaches a high vocabulary mastery level and finally he can reach a maturity level to communicate in his freely. According to Harris and Sipay (1980: 270), high vocabulary mastery is a maturity signal.

\section{Reading Comprehension}

\section{The definition of Reading Comprehension}

According to Broughton, et al (1980:89), "Reading is a complete skill, that is to say that it involves a whole series of lesser skills. "First of these is the ability to recognize stylized shapes which are figures on a ground, curves and lines and dots in patterned relationship. The second of the skills involved in the complex is the ability to correlate the black marks on the paper-the patterned shapes -with language. A third skill which is involved in the total skill of reading is essentially an intellectual skill: this is the ability to correlate the black marks on the paper by way of the formal elements of language, let us say the words as sound, with the meanings which those words symbolize.

Effective communication happens only when meanings from the communicator to the communicant are comprehended. Comprehension is addressed in psycholinguistics. Comprehension refers to how people understand spoken and written language. Gleason and Ratner ( $1998: 3$ ) state that comprehension is a broad area of investigation that involves scrutiny of the comprehension process at many levels, including investigation of how speech signals are interpreted by listeners ( speech perception ) ; how the meanings of words are determined ( lexical access ); how the grammatical structure of sentences is analyzed to obtain larger units of meaning ( sentence processing ) ; and how longer conversations or text are appropriately formulated and evaluated ( discourse ). It also concern specifically relevant to how written language is processed. Mc Neil ( $1992: 16$ ) asserts that comprehension is making sense out of text. In the early stages of learning to read, comprehension is hampered by limited: capacity of processing space, attention, prior knowledge, and atomization of processes ( procedures ) are all part of skilled reading 
Reading comprehension is acquiring information from context and combining disparate elements into a new whole. It is the process of using one's existing knowledge ( schemata) to interpret text in order to construe meaning. Although a writer structures the texts for different purposes, readers must interpret what is read and must arrive at reader's own construction of what the text as well a the changing of the knowledge one used to understand the text in the first place.

According to Alderson ( 1984,p. 95 ) "The reading comprehension process focuses on three elements: The text being read, the background knowledge possessed by the reader, and conceptual aspects". He suggests that background knowledge is a helpful tool when a person confronts a text since he can recognize his knowledge and put it together better. To comprehend a reading it is necessary that the reader can extract the key words in order to capture the whole sense of the text.

A writer uses language to convey the message to the readers. Language enables the exchange of information, knowledge, thoughts and ideas in spoken and written. A great deal of the world's scientific, commercial, economic, and technological knowledge is written and published in English. Reading is the activity to get information, knowledge, thoughts, and ideas. Therefore, the ultimate goal in reading is course to make meaning from the text that is comprehend the information that is conveyed in the text. Richard ( 1992 ) says that reading comprehension refers to the understanding that result from perceiving a written text.

\section{Expository Text}

Expository text is a type of text that the students most encounter in the daily life because the students read a non fiction book, magazine, or newspaper article. The author uses expository writing to inform the reader about the topic. At schools, students are also requires to submit school exams research papers as a means for the teachers to grade the progress. Gerot and Wignell ( 1994:192-217)explains that exposition is to persuade the reader that something is the case or to expose the case to the reader and its schematic structure is Thesis Arguments Conclusion .D'angelo ( $1980: 188)$ says that expository text is written by authors to inform, to explain, to describe and to present . Expository writing is a type of writing where the purpose is to inform, describe, explain, or define the author's subject to the reader. Expository text is meant to deposit information and is the most frequently used type of writing by students in elementary schools, middle schools, high schools, colleges and universities. A wellwritten exposition remains focused on its topic and lists events in chronological order. Examples of expository writing include driving directions and instructions on performing a task. Key words such as first, after, next, then, last, before that, and usually signal sequential writing. Second-person instructions with "you" are acceptable. However, the use of first person pronouns should be avoided (For example, I, I think, I believe etc...). Expository essays should not reveal the opinion of the author or writer.

Exposition is a type of writing that is used to explain, describe, give information or inform on what is being discussed. One important point to keep in mind for the author is to try to use words that clearly show what they are talking about rather than blatantly telling the reader what is being discussed. Since clarity requires strong organization, one of the most important mechanisms that can be used to improve the writer's skills in exposition is to provide directions to improve the organization of the text. It tells readers about the information in the selection. Information in this format relates to the reader as a whole with details that describe importance.

\section{RESEARCH METHODOLOGY}

The method used in the research was a survey. Data of grammar mastery, vocabulary mastery and reading comprehension were acquired from the tests. The data was analysed using descriptive statistical method, multiple correlation coefficient, determination coefficient and regression analysis. To test the statistics is used $\mathrm{T}$ test and $\mathrm{F}$ test. Variables being researched in this researched are Independent Variable ( X1 ) : Grammar Mastery, Independent Variable ( X2 ) : Vocabulary Mastery and Dependent Variable ( $\mathrm{Y}$ ) : Reading Comprehension in expository test

\section{RESULT AND DISCUSSION}

\section{A. The Data Description}

We will present the statistic description from the calculation and testing through computer SPSS 16.00 program, within the analysis and interpretation. The data description is the analysis to know the range of the data, average, median, mode and standard deviation 
Table 1. The Data Description Result

\begin{tabular}{|l|r|r|r|}
\hline & Statistics \\
\hline N Valid & X1 & X2 & Y \\
$\quad$ Missing & 40 & 40 & 40 \\
Mean & 0 & 0 & 0 \\
Std. Error of Mean & 63.75 & 62.25 & 62.25 \\
Median & 1.506 & 1.66 & 2.041 \\
Mode & 60 & 60 & 60 \\
Std. Deviation & 60 & 60 & 60 \\
Variance & 90.524 & 10.497 & 12.907 \\
Range & 90.705 & 110.192 & 166.603 \\
Minimum & 30 & 40 & 50 \\
Maximum & 50 & 40 & 40 \\
Sum & 80 & 80 & 90 \\
& 2550 & 2490 & 2490 \\
\hline
\end{tabular}

The average score of Grammar Mastery that is acquired from the respondent are 63.75 within standard deviation of 9.524 ; median of 60.00 ; minimum score of 50.00 and maximum score of 80.00

The average score of Reading Comprehension that is acquired from the respondent are 62.25 within standard deviation of 12.907; median of 60.00 ; minimum score of 40.00 and maximum score of 80 .
The average score of Vocabulary Mastery that is acquired from the respondent are 62.25 within standard deviation of 10.497 ; median of 60.00 ; minimum score of 40.00 and maximum score of 80.00 .

The result of calculation and test can be seen in Table 2, table 3, and table 4.

Table 2. The Calculation Result of Coefficient Correlation The Effect of Variable $X_{1}$ and $X_{2}$ toward Variable Y

Model Summary ${ }^{b}$

\begin{tabular}{|c|c|c|c|c|c|c|c|c|c|}
\hline \multirow[b]{2}{*}{ Model } & \multirow[b]{2}{*}{$\mathrm{R}$} & \multirow[b]{2}{*}{$\begin{array}{c}\mathrm{R} \\
\text { Square }\end{array}$} & \multirow[b]{2}{*}{$\begin{array}{c}\text { Adjusted R } \\
\text { Square }\end{array}$} & \multirow[b]{2}{*}{$\begin{array}{l}\text { Std. Error of } \\
\text { the Estimate }\end{array}$} & \multicolumn{5}{|c|}{ Change Statistics } \\
\hline & & & & & $\begin{array}{l}\text { R Square } \\
\text { Change }\end{array}$ & F Change & df1 & df2 & $\begin{array}{c}\text { Sig. F } \\
\text { Change }\end{array}$ \\
\hline 1 & $.780^{\mathrm{a}}$ & .608 & .587 & 8.293 & .608 & 28.737 & 2 & 37 & .000 \\
\hline
\end{tabular}

a. Predictors: (Constant), X2, X1

Table 3. The Result Recapitulation Significant Coefficient Regression Test the Effect Variable $\mathrm{X}_{2}$ within Variable Y

ANOVA $^{b}$

\begin{tabular}{|ll|r|r|r|r|r|}
\hline Model & & Sum of Squares & df & Mean Square & \multicolumn{1}{c|}{ F } & \multicolumn{1}{c|}{ Sig. } \\
\hline 1 & Regression & 3952.827 & 2 & 1976.414 & 28.737 & $.000^{\mathrm{a}}$ \\
& Residual & 2544.673 & 37 & 68.775 & & \\
& Total & 6497.500 & 39 & & & \\
\hline
\end{tabular}

a. Predictors: (Constant), X2, X1

b. Dependent Variable: Y 
Table 4. The Result Recapitulation of Equation of a Regression Line Calculation The Effect of Variable $\mathbf{X}_{1}$ and $X_{2}$ toward Variable $Y$

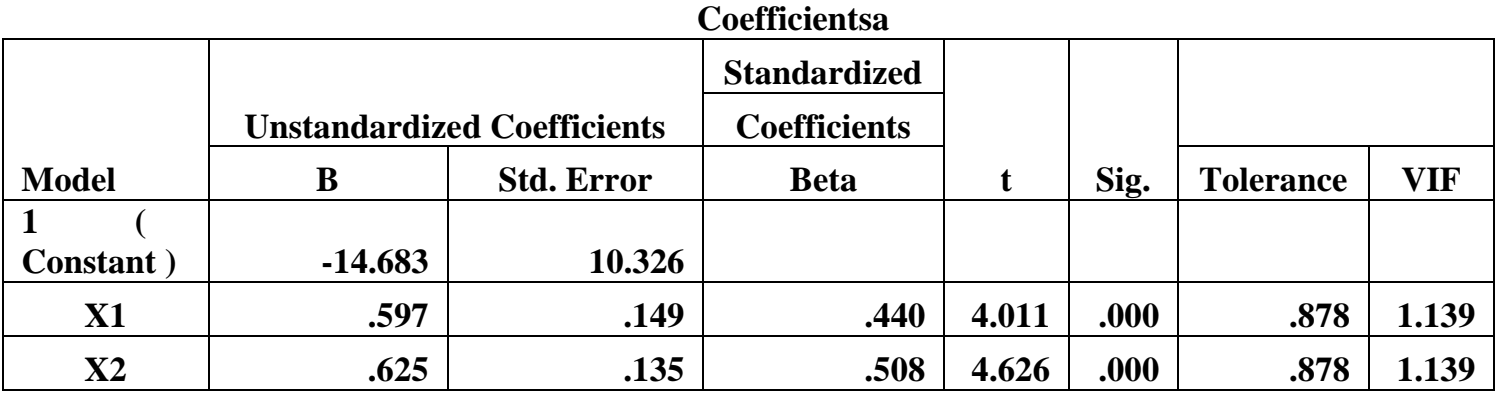

a.

Dependent Variable : Reading Comprehension on Expository Text

1. The Effect of Vocabulary Mastery ( $\left.X_{1}\right)$ and Logical Thinking $\left(\mathrm{X}_{2}\right)$ towards Student's Listening Skill ( Y )

\section{This hypothesis effects is :}

Ho $=0 ; \beta 2=0$

$\mathrm{H} 1 ; \beta \neq 0 ; \beta 2 \neq 0$

Ho : there is no significant effect between grammar mastery $\left(X_{1}\right)$ and vocabulary mastery $\left(X_{2}\right)$ towards student's reading comprehension in expository text ( Y )

H1 : there is significant effect between grammar mastery $\left(X_{1}\right)$ and vocabulary mastery $\left(X_{2}\right)$ towards student's reading comprehension in expository text ( Y )

From table 4.5 we can see that the effect of double coefficient correlation of independent variable grammar mastery $\left(X_{1}\right)$ and vocabulary mastery ( $\mathrm{X}_{2}$ ) toward student's reading comprehension in expository text ( $\mathrm{Y}$ ) is 0,780

The calculation of significant coefficient correlation test can be seen in table 4.5. From the calculation, acquired that coefficient correlation is significant in other word that there is a significant effect of independent variable of grammar mastery $\left(X_{1}\right)$ and vocabulary mastery $\left(\mathrm{x}_{2}\right)$ towards student's reading comprehension in expository text ( $\mathrm{Y})$.

While coefficient determination is 0,608 show that the quantity of the effect of grammar mastery and vocabulary mastery towards student's reading comprehension in expository text is $60,8 \%$ and reside is $39,2 \%$ because of another factor.
The hypothesis test through the regression analysis acquired the calculation result that can be seen in table 4.6 and table 4.7. From the table 4.7 acquired the equation of regression line that represent the effect of $\mathrm{X}_{1}$ and $\mathrm{X}_{2}$ toward variable $\mathrm{Y}$, that is $\ddot{\mathrm{Y}}=$ $47,940+0,157 \mathrm{X} 1+0,335 \mathrm{X}_{2}$. The significant test for regression line is by paying attention to the result on table 4.6. Based on the rule, the criteria for significant regression is " if $\mathrm{Sig}<0,05$ so Ho denied" or "if $F_{\text {test }}>F_{\text {table }}$ Ho is denied ", it means that the coefficient regression is significant, in other word there is a significant effects of dependent variable $\mathrm{X}_{1}$ and $\mathrm{X}_{2}$ toward independent variable $\mathrm{Y}$. The score $\mathrm{f}$ Sig is the number printed in Sig column in table 4.6. While $F_{\text {table }}$ is the score of distribution table $\mathrm{F}$ for real standard is $5 \%$ with the numerator degree $(\mathrm{k})=2$ and denominator degree $(n-k-1)=$ 37 while $\mathrm{n}$ is the respondents, and $\mathrm{k}$ is the quantity of dependent variable.

From table 4.6 .it can be seen that the score of Sig = 0.000 and $F_{\text {test }}=28,737$; while $F_{\text {table }}=3,27$. Because the score of sig $<0,05$ and $F_{\text {test }}>F_{\text {table }}$ so Ho is denied means that the coefficient regression is significant. In other word, there is a significant effect of independent variable of grammar mastery $\left(X_{1}\right)$ and vocabulary mastery $\left(X_{2}\right)$ towards students' reading comprehension in expository text.

2. The Effect of Grammar Mastery ( $\left.\mathbf{X}_{1}\right)$ towards students's reading comprehension in expository text

This hypothesis effect is :

Ho : $\beta y 1=0$

$\mathrm{H} 1: \beta y 1 \neq 0$ 
Means :

Ho : there is no significant effect of vocabulary mastery towards student's reading comprehension in expository text

H1 : there is no significant effect of vocabulary mastery towards student's reading comprehension in expository text

To prove the hypothesis is by paying attention to the score of column $\mathrm{t}$ or column Sig for line grammar mastery ( variable $\mathrm{X}_{1}$ ) on the Table 4.7 Based on the rule, the criteria for significant regression is the number "if Sig $<0.05$ so Ho denied " or $\mathrm{F}_{\text {test }}>\mathrm{F}_{\text {table }}$ so Ho denied', means that the coefficient regression is significant, of dependent variable $\mathrm{X}_{1}$, toward dependent variable $\mathrm{Y}$. The score if Sig is the number printed in column Sig for Grammar Mastery ( variable $\mathrm{X}_{1}$ ) in table 4.7.The score of $\mathrm{t}$ test is the number shown 1 column $\mathrm{t}$ for grammar mastery line ( variable X1 ) in table 4.7 .While the score for $t_{\text {table }}$ is the score of distribution $t$ for the standard real $5 \%$ with the degree freedom ( $\mathrm{df}+\mathrm{n}-2$ ) $=38$ while $\mathrm{n}$ is the quantity respondents. From table 4.7 can be seen that the score of Sig = 0.000 and $t_{\text {test }}=4,011$; while $t_{\text {table }}=2,05$. Because the score of Sig $<0.05$ and $t_{\text {test }}>t_{\text {table }}$ so Ho is denied that means there is a significant effect of independent variable $\mathrm{X}_{1}$ ( grammar mastery ) towards dependent variable $\mathrm{Y}$ ( reading comprehension )

From the result of correlation test $m$ regression test or by seeing the line model we may conclude that there us a significant effect of independent variable $\mathrm{X}_{1}$ ( grammar mastery ) towards dependent variable Y ( reading comprehension )

3. The Effect of Vocabulary Mastery ( $\left.X_{1}\right)$ towards students' reading comprehension in expository text

This hypothesis effect is :

Ho : $\beta y 1=0$
H1 : $\beta y 1 \neq 0$

Means :

Ho : there is no significant effect of vocabulary mastery towards student's reading comprehension in expository text.
H1 : there is no significant effect of vocabulary mastery towards student's reading comprehension in expository text.

\section{B. Research Findings}

The purpose of this research is to find the effect of grammar mastery and vocabulary mastery towards student's reading comprehension in expository text.

1. The Effect of Grammar Mastery and Vocabulary Mastery towards students' reading comprehension in expository text

From the descriptive analysis after the correlation analysis has been done acquired coefficient of 0,780 and coefficient determination of $60,8 \%$ after the testing by using SPSS program proved that the coefficients correlation is significant. It means that there is effect of dependent variable $\mathrm{X}_{1}$ ( grammar mastery ) and $X_{2}$ ( vocabulary mastery ) toward dependent variable $\mathrm{Y}$ ( reading comprehension ).

And from the regression analysis the equation of regression line $\ddot{Y}=-14.683+0.597 X_{1}+0,625 X_{2}$. The constant score $=-14,683$ showed that with a low grammar mastery and vocabulary mastery make students difficult to improve a good reading comprehension skill, while the score of coefficient regression of 0,597 and 0,625 showed that there is a positive effect of independent variable $X_{1}$ ( grammar mastery ) and $\mathrm{X}_{2}$ ( vocabulary mastery ) towards dependent variable $\mathrm{Y}$ ( reading comprehension). Every increase of one score of grammar mastery will make another increase in reading comprehension of 0,597 , and every increase of one score of grammar mastery will make another increase in reading comprehension of 0,625.After the test of regression line linearity by using SPSS program acquired the regression line is linear. From the significant test of coefficient regression that is also used the SPSS program acquired that the coefficient regression is significant, means that it is true that there is a positive effect of independent variable $\mathrm{X}_{1}$ ( grammar mastery ) and $\mathrm{X}_{2}$ ( vocabulary mastery ) toward dependent variable $\mathrm{Y}$ ( reading comprehension ).

With a higher grammar mastery and vocabulary mastery will also make the students have a higher reading comprehension skill. From the quantitive information and theory, the researcher draw a conclusion that grammar mastery and vocabulary mastery have a significant effect towards reading comprehension of the students. One score of 
grammar mastery will make another increase in reading comprehension of 0,157 .

\section{The effect of Grammar Mastery toward student's reading comprehension}

From the hypothesis test acquired the score of Sig = 0.000 and $t_{\text {test }}=4.011$, while $t_{\text {table }}=1,98$. Because the score of $\mathrm{Sig}<0,05$ and $\mathrm{t}_{\text {test }}>\mathrm{t}_{\text {table }}$ so Ho is denied it means that there is a significant effect of independent variable $\mathrm{X}_{1}$ ( grammar mastery ) towards dependent variable $\mathrm{Y}$ ( reading comprehension ). From the quantitive information and theory, the researcher draw a conclusion that the grammar mastery has a significant effect towards student's reading comprehension.

\section{The effect of Vocabulary Mastery toward student's reading comprehension}

From the hypothesis test acquired the score of Sig = 0.000 and $t_{\text {test }}=4.626$, while $t_{\text {table }}=1,98$. Because the score of Sig $<0,05$ and $t_{\text {test }}>t_{\text {table }}$ so Ho is denied it means that there is a significant effect of independent variable $\mathrm{X}_{1}$ ( grammar mastery ) towards dependent variable $\mathrm{Y}$ ( reading comprehension ) .From the quantitive information and theory, the researcher draw a conclusion that the vocabulary mastery has a significant effect towards students' reading comprehension.

\section{BIBLIOGRAPY}

Alderson, J. Charles ( 2000). Assesing Reading. Uk: Cambridge University Press

Allington, Richard, and Strange, Michael. (1980).Learn Through reading in the content Areas. USA: D.C. Heath and Company.

Ames, W.S. (1964). The Understanding of Vocabulary of the First Grade Pupils. Elementary English 41 ( January )

Atkinson, Rita L, et al,.(1983). Introduction to Psychology. New York : Harcourt Brace Javanovich publisher. Eight edition.

Block, E.(1986).The Comprehension Strategies of Second Language Readers. TESOL Quarterly,
Broughton, Geofrrey, et al.(1978) Teaching English as Foreign Language, New York: Routledge \& Kegan Paul ltd

Brown, H.D.(1994) Principles of Language Learning and teaching. Englewood Cliffs, New Jersey: Prentice Hall, Inc.

Carrel, P.I., Joanne, D., and David, E.e.(1988) Interactive Approach to Second Language Reading, Cambridge University Press

Dawson, Milred A., and Bamman, Henry A.(1967) Fundamentals of Basic Reading Instruction, Newyork: David Mc kay Company, Inc

Davis, F. B.(1968) Research in Comprehension in Reading, Reading Research Quartley 3 ( Summer )

D’Angelo, F.J.(1980 ). Process and Thought in composition. Boston: Houghton Miffin.

Deboer, John, and Dallman, Martha. ( 1964) The Teaching of Reading. USA : Holt, Richard and Winston , Inc

Du Troit, A. and orr. ( 1987). Archiever's Handbook. Johannesburg : Southern Book Publishers.

Day, Richard R. ( 1993) New Ways in Teaching Reading., USA; TESOL Inc

Dubin F. and Eskey, D. E. and Grabble ( 1986 ) W. Teaching Second Language Reading for Academic Purposes. California: EdisonWeskey Publishing Company

Frank, M. ( 1972 ). Modern English : A Practical Reference Guide. Englewood Cliffs, New Jersey : Prentice_Hall

Harmer, Jeremy. (1983). The Practise of English languageTteaching . London: Longman Inc

Harris, Larry A. and Smith, Carl B. ( 1980). Reading Instruction : Diagnostic Teaching in the Classroom, New York : Richard C. Owen Publisher

Hughes, Arthur. ( 2003 ). Testing for Language Teacher. UK : Cambridge University Press

Gairns, Ruth and Redman Stuart. (2003). Working With Words: A guide to Teaching and Learning Vocabulary., UK: Cambridge University Press, Fifteenth Printing 
Gerot, I., \& Wignell, P.(1994) Making Sense of Functional Grammar, Sydney : Gerd Stabler

Gleason, B.J. and Ratner ( 1998) Psycholinguistics. New York : Harcourt Brace Collage Publishers

Grellet Franchoise, (2010). Developing Reading Skills, UK: Cambridge University press, $29^{\text {th }}$ Printing

Goodman, Y. M., and Burke , C. (1980). Reading Strategies : Focuesed on Comprehension. New York: Holt, Rinehart and Winston

Harmer, Jeremy. (1983). The Practise of English languageTteaching . London: Longman Inc

Harris, Larry A. and Smith, Carl B. ( 1980). Reading Instruction : Diagnostic Teaching in the Classroom, New York : Richard C. Owen Publisher

Hughes, Arthur. ( 2003 ). Testing for Language Teacher. UK : Cambridge University Press

Hornby, A.S. (1995). Oxford Advanced learner's Dictionary of Current English. Oxford New York: Oxford press University

Jackson, H.(2000). Words, Meaning and Vocabulary. An Introduction to Modern lexicology, The Crownwell Press

Kamil, M.L., Amd Hierbert, E. (2004). The Teaching and learning of Vocabulary Perspective and persistent Issues. Mahwah: W.J. Earlbraum

Kerlinger, N. ( 1970). Foundation of Behavioral Research. New York : Holt, Rinehart and Winston

Lynn, M. N.(2007). The Effects of Explicit Instructions of Expository Text-Structure Incorporating Graphic organizers on the Comprehension of Third Grade Students, ProQuest Information and Learning

Mc Neil, J.D. ( 1992 ). Reading Comprehension . New York : Harper Collins Publisher

Nation, L.S.P. (1990) Teaching and Learning Vocabulary, Massachusetts: Heinle \& Heinle Publishers

Norbert, S.( 1997). Decriptive, Acquisition and Pedagogy. Cambridge University Press
Nunan, David.(1992) Research Methods in Language Learning, New York: Cambridge University Press

Oxford, R.L., and Crookall, D. ( 1989 ). Research in Language Learning Strategies in an Intensive Foreign Language program in the United States. System, 23 ( 3), 359-386

Readence, J. C. (1985). The Context of Language Teaching, Iowa : Kendall Hunt Publishing Company

Read, John.(2000). Assessing Vocabulary., UK Cambridge University Press

Richards, Jack C and Rogers, Theodore S. (2001). Approaches and Methods in Language Teaching, second edition, UK: Cambridge University Press

Richard, J.C. ( 1985). The Context of Language Teaching. New York : Cambridge University Press

Riemsdijk, H. V.(1998). and William, S. E., Introduction to the Theory of Grammar, England : The Massachusetts Institute of Technology Press

Robert, J. ( 1995). Reading Strategies and Practises. Allyn and Bacon, Inc

Savage, John F.( 1979 ) Teaching Reading to Children with Special Needs, Massachussets : Allyn and Bacon Inc

Savignon, S. ( 1983). Communicative Competence: Theory and Classroom Practice. USA : Addison- Weley Publishing Company Inc.

Thornbury, Scott.(2002) How to teach Vocabulary, England: Pearson education Limited

Vei, R.( 1986). Discovering English Grammar. Boston : Houghton Mifflin Company

Wallace, M. ( 1982). Teaching Vocabualary. Guidford: Surrey : Biddles Ltd 
The Effects Of Grammar Mastery And Vocabulary Mastery Towards Student's Reading Comprehension In Expository Text

\section{PROFIL PENULIS}

Etik Dwi Styaningrum lahir pada tanggal 25 Maret 1975. Lulus S1 dari Universitas Sanata Dharma Jogjakarta jurusan Pendidikan Bahasa Inggris dan Universitas Gadjah Mada Jurusan Ilmu Komunikasi. Mengambil S2 di Universitas PGRI Indrapasta jurusan Pendidikan bahasa Inggirs dan lulus tahun 2014. Mengajar di Bina Sarana Informatika sejak tahun 2001. Hp : 08138113490 dan email : etik.eds@bsi.ac.id 